\title{
Coexistence of musculoskeletal disorders in the upper body of labor origin
}

\section{Coexistencia de trastornos musculoesqueléticos en miembro superior de origen laboral}

\author{
Adriana Guzmán-Velasco ${ }^{10}$, José Luis Diago-Franco²
}

Typolgy: Article of Scientific and technological research articles

To cite this article: Guzman A, Diago J. Coexistence of musculoskeletal disorders in the upper body of labor origin. Duazary. 2019 may; 16(2): 193-203. Doi: https://doi.org/10.21676/2389783X.2749

Received on June 29, 2018

Accepted on January 22, 2019

Published online february 20, 2019

\begin{abstract}
The coexistence of musculoskeletal disorders is common in work activities around the world, however, information on the subject is insufficient both in Latin America and in Colombia despite its impact at the economic and social level. The objective of this research was to determine the coexistence of musculoskeletal disorders of work origin in the upper body in the working population that attends a Service Provider Institution (IPS). An observational, descriptive, quantitative, and cross-sectional design study was conducted between the first of March in 2017 and the first of March in 2018. Four semiological tests were applied for physiotherapists to seek the coexistence of carpal tunnel syndrome, lateral epicondylitis, rotator cuff syndrome, and cervical myofascial syndrome. Among the results, it was found that $92.6 \%(n=138)$ of the patients had two or more pathologies, 59.73\% $(n=89)$ had the rotator cuff and the myofascial syndrome, $52.35 \%(\mathrm{n}=78)$ had epicondylitis and myofascial syndrome, and $37.58 \%(\mathrm{n}=56)$ had carpal tunnel syndrome and lateral epicondylitis. This study highlights the high coexistence of musculoskeletal disorders in the upper body, especially in the female gender.
\end{abstract}

Keywords: Musculoskeletal Diseases; Tennis Elbow; Carpal Tunnel Syndrome; Painful shoulder syndrome; Rotator cuff syndrome; Occupational exposure.

\section{RESUMEN}

La coexistencia de trastornos musculoesqueléticos es común en actividades laborales de todo el mundo, sin embargo la información sobre el tema es insuficiente tanto en América Latina como en Colombia a pesar de su impacto a nivel económico y social; la investigación tuvo como objetivo determinar la coexistencia de trastornos musculoesqueléticos en miembro superior de origen laboral en la población trabajadora que asiste a una Institución Prestadora de Servicios (IPS); Se realizó un estudio de diseño Observacional, descriptivo, cuantitativo y de corte transversal, durante el periodo comprendido entre el primero de marzo de 2017 y el primero de marzo del 2018, se aplicaron cuatro pruebas semiológicas por fisioterapeutas para buscar la coexistencia de Síndrome de túnel del

1. Universidad del Cauca. Popayán, Colombia. Email: aguzman@unicauca.edu.co - http://orcid.org/0000-0001-5233-262X

2. Universidad del Cauca. Popayán, Colombia. Email: diagofrancojoseluis@gmail.com - http://orcid.org/0000-0002-9669-7978 
carpo, epicondilitis lateral, síndrome de manguito rotador y síndrome miofascial cervical; entre los resultados se encontró que el 92,6\% ( $\mathrm{n}=138)$ de los pacientes presentaban dos o más patologías, el 59,73\% ( $\mathrm{n}=89)$ síndrome de manguito rotador y síndrome miofascial, el 52,35\% (n=78) Epicondilitis y síndrome miofascial y el 37,58\% síndrome de túnel del carpo y epicondilitis lateral $(n=56)$. El estudio pone en evidencia la elevada coexistencia de trastornos musculoesqueléticos en miembro superior especialmente en el género femenino.

Palabras clave: enfermedades musculoesqueléticas; codo de tenista; síndrome del túnel carpiano; síndrome de hombro doloroso; tendinitis del manguito rotador; exposición ocupacional.

\section{INTRODUCTION}

A ccording to the World Health Organization $(\mathrm{WHO})^{1}$, musculoskeletal diseases (MSD) are one of the leading causes of workplace absenteeism and a promoter of the high costs of the public health system. MSDs are defined by $\mathrm{WHO}^{1}$ as a health problem of the locomotion mechanism that affects the muscles, tendons, bones, cartilage, ligaments, and nerves, having a multifaceted origin that can be caused or aggravated by occupational risk factors.

According to the International Labor Organization $^{2}$ (ILO), each year around 160 million new cases of nonfatal occupational diseases are reported. These are the second leading cause of solicitations for economic benefits due to disability in countries that are part of the Organisation for Economic Cooperation and Development ${ }^{3}$. In Europe these these illnesses affect more than 40 million workers, and generate temporary incapacity in $50 \%$ of the cases of work origin MSD and permanent disability in $60 \%{ }^{4}$. In Colombia, the Federation of Insurers ${ }^{5}$ (Fasecolda) reported in 2013 over 40,000 occupational diseases, of which $88 \%$ were MSD. In the same manner, Fasecolda ${ }^{5}$ and the latest Guide of Integral Attention Based on the Evidence for Musculoskeletal Disorders in Colombia ${ }^{6}$ have determined that the majority of diagnostics correspond to the upper body and spine.
Despite the fact that MSDs of work origin in the spine and upper body are commonplace in countries all over the world, the ability of statistical data is uneven and most of it comes from high income economies like the United States ${ }^{6}$, with a prevalence that varies according to the country due to basic demographic indicators, factors related to health and employment, work conditions, and the instruments utilized for their evaluation $^{3,7}$.

Mohammadpour et $a l^{8}$, among other authors, signal that exposure to occupational risk factors affect mostly the meck, back, and the upper extremities. Nevertheless, through a study conducted in the year 2017 in three Spanishspeaking countries, Campos et al warns that no study has evaluated the simultaneous effect of various anatomical sites in the upper extremities- an expression defined for this text as coexistence, meaning the existence of two or more concomitant MSDs or two or more MSDs simultaneously occurring in the same extremity caused, in this case, by the performance of workplace activities.

The lack of knowledge about the coexistence of MSDs in one extremity is also reflected in the Evidence Based Attention Guides ${ }^{6}$, where the treatment is circumscribed to a specific anatomical site and not to a complete body structure. Pilat $^{9}$ proposes the human body's functional 
anatomy should be treated from an integrally structural perspective that allows the establishment of a relationship between the MSDs, the biomechanical malfunctions that frame inadequate movement patterns, and that focus should be given to treatment to achieve the workers' successful rehabilitation and their reinsertion to their workplace activities.

As a result, without taking into account the coexistence or concomitance of various MSDs, the direction of treatment increases the consequences for the worker while causing a delay in the worker's rehabilitation, lowers the quality of life, and generates less productivity at work ${ }^{8}$. This situation impoverishes workers, and it can damage entire communities to lose its most productive company workers. As stated by $\mathrm{OIT}^{2,10}$, this setting generates elevated costs to workers and their families, and it affects the countries' economic and social development to have a loss of $4 \%$ in each country's gross domestic product (GDP).

Having in mind the large scale economic impact of professional diseases, the insufficient information from Latin America and Colombia about work conditions, their effect on workers' health- in particularly on a musculoskeletal level ${ }^{7}$ - and the absence of literature that identifies the incidences of MSDs that occur in a simultaneous fashion in the upper body, the objective is to determine the coexistence of upper body musculoskeletal disorders originating in the workplace in the working class that attend an institution that provides rehabilitory services (IPS) in the city of Popayán.

\section{MATERIALS AND METHODS}

\section{Type of Study}

An observational, descriptive, quantitative, and cross-sectional study was realized in the period included between the first of March of 2017 and the first of march of 2018.

\section{Population and Sample Size}

The study was carried out in a private sector physical rehabilitation center linked to the general Colombian social security system. 149 patients with different kinds of occupations were recruited for this study. Formal workers were referred by an occupational physician while informal workers were referred by a general physician who registered the association of the MSD with the work activity done by the patient in the clinic's history.

In order to be eligible for the study, patients had to display MSD in the neck and upper body. Workers with musculoskeletal disorders due to referred or visceral pain were discarded. The number of patients presented during the specified period with the previously mentioned characteristics and that had signed the informed consent form determined the sample size.

\section{Procedure}

For the implementation of this study, patients identified by the inclusion and exclusion criteria were first told about the offer, having the objectives and work plan explained to them. Following that, four semiological trials were applied by the physiotherapists from the IPS in order to determine the coexistence of at least two of the following MSDs in the same patient: carpal tunnel syndrome, lateral epicondylitis, rotator cuff syndrome, and cervical myofascial syndrome.

Tinel's sign was used, through which Carpal Tunnel is realized being generated as a stimulus over the median nerve. The reproduction of paresthesia accompanied by pain was registered as a Positive Tinel $^{11}$ (Figure 1a). 
As to lateral epicondylitis, the patient was asked to extend the wrist against manual resistance aimed at the muscles of the external compartment of the elbow. The trial was considered positive at the emergence of pain and functional impotence ${ }^{11}$ (Figure $1 b$ ). In respect to rotator cuff syndrome, abduction $\left(90^{\circ}\right)$ from a neutral position of the glenohumeral joint was asked of the patient, and manual resistance was applied.
Evidence of pain and functional impotence indicated presence of the syndrome ${ }^{11}$. (Figure 1c).

In relation to cervical myofascial syndrome, a manual stimulus was applied to the occipitocranial, upper trapezius, and levator scapula and interscapular trigger points. The syndrome was made evident with the appearance of pain and the withdrawal sign ${ }^{11}$ (Figure 1d).

Figure 1. Source: Hormiga ${ }^{30}$ : a) carpal tunnel syndrome; b) lateral epicondylitis; c) rotator cuff syndrome; d) cervical myofascial syndrome.

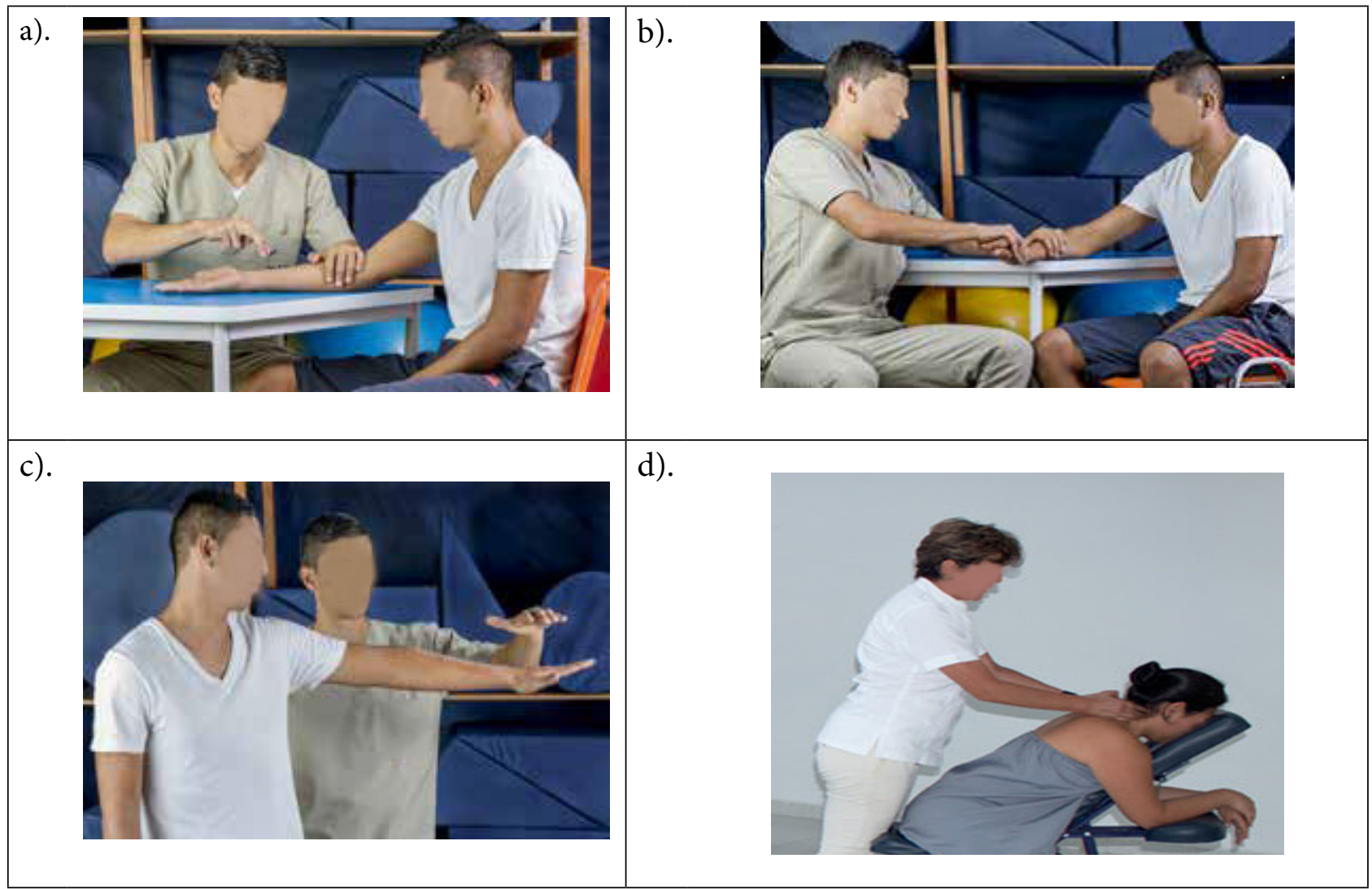

\section{Statistical Analysis}

A field journal in Excel was used for the collection of data. In it, information related to gender, occupation, age, seniority in position, and a registra- tion of the results of the semiological trials was consolidated. For the statistical analysis, the data was processed in SPSS version 17.0. A descriptive analysis of numerical and nominal data was made, a baseline was established for the variables 
using the Kolmogorov-Smirnov test with the significance Lilliefors corrected, the correlation between the quantitative variables was explored using Spearman's coefficient (rho) and a correspondence analysis using chi-squared test, with a confidence interval of $95 \%$ and a value of $\mathrm{p}<0.05$ accepted as statistically significant.

\section{Declaration of ethical aspects}

Ethical considerations were based on the Declaration of Helsinki ${ }^{12}$, 1993's resolution 8430 of scientific investigation in Colombia which cataloged it as a no-risk study ${ }^{13}$, and 2012's law 1581 that overviews the protection of personal information ${ }^{14}$. The principles of totality, integrity, respect towards patients, the right to no maleficence, autonomy, welfare, justice, and equity were fulfilled, and the approval of the Committee of Investigations in the Faculty of Health Sciences in the University of the Cauca was accounted for. Participation was free and voluntary, and informed consent forms were signed giving participants the possibility to refuse or abandon the study at any time without any penalty.

\section{RESULTS}

Between March first, 2017 and March first, 2018, 149 patients with MSD in the upper body were evaluated, $100 \%(n=149)$ of which had some form of link to employment and performing diverse types of occupational roles. The gender distribution was $70 \%(\mathrm{n}=105)$ feminine and $30 \%(\mathrm{n}=44)$ masculine.

The average age was $50.4(\mathrm{~s} \pm 13.96)$ years old for the entire sample population, 55.8 ( $\mathrm{s} \pm$ 13.32;
Mo 57) for those of the female gender, and 51.8 ( $\mathrm{s} \pm$ 14.74; Mo 57) for the male gender. The sample population in general had an average of 18.76 years of work experience, each in distinct areas. The women had an average of 18.97 years of work experience and the men 18.25. The numerical age and professional experience variables did not follow a normal distribution, but there was a positive or directly proportional correlation. In order to explore the correlation between the mentioned variables the Spearman coefficient (rho) was applied, finding a positive association between both variables, establishing a relation directly proportional between age and general professional experience.

$25 \%(n=11)$ of the men and $20 \%(n=11)$ of the women had vocational training. All of the pensioners were exclusively male, with a figure of $22.73 \%(n=10)$, though they still worked independently in commercial activities.

Since the participants were those who benefited from social security, activities linked to unprivileged administrative jobs were predominant in a manner surpassing a specific trade. 51 occupations were registered, grouped in five categories according to how similar each workplace activity performed was: Administrative (professionals and technologists who work in offices), Various occupations (in the case of women paid word related to the household, and in men activities of carpentry, gardening, and exterior cleaning). $100 \%$ of the women worked in activities related to the home, nevertheless only $34.22 \%(n=51)$ received payment for working in places other than their homes (Table 1). 
Table 1. Grouping of jobs and professions according to gender.

\begin{tabular}{|l|c|c|c|c|c|c|}
\hline \multicolumn{1}{|c|}{ Groups } & \multicolumn{2}{c|}{ Masculine } & \multicolumn{2}{c|}{ Feminine } & \multicolumn{2}{c|}{ Total } \\
\hline & $\mathrm{n}$ & $\%$ & $\mathrm{n}$ & $\%$ & $\mathrm{n}$ & $\%$ \\
\hline Administrative & 16 & 10.73 & 49 & 32.88 & 65 & 43.61 \\
\hline Various occupations & 5 & 3.35 & 51 & 34.22 & 56 & 37.57 \\
\hline Commerce & 14 & 9.39 & 5 & 3.35 & 19 & 12.71 \\
\hline Transport & 6 & 4.02 & 0 & 0 & 6 & 4.02 \\
\hline Agricultural Activities & 3 & 2.01 & 0 & 0 & 3 & 2.01 \\
\hline Total & $\mathbf{4 4}$ & $\mathbf{2 9 . 5}$ & $\mathbf{1 0 5}$ & $\mathbf{7 0 . 3 5}$ & $\mathbf{1 4 9}$ & $\mathbf{1 0 0}$ \\
\hline
\end{tabular}

In respect to medical referrals, it was found that $63.7 \%(\mathrm{n}=95)$ of patients presented rotator cuff syndrome, 23.4\% $(n=35)$ carpal tunnel syndrome, $12 \%(n=18)$ lateral epicondylitis, and $10 \%(n=15)$ cervical myofascial syndrome. $7.3 \%(\mathrm{n}=11)$ showed simultaneous carpal tunnel syndrome and rotator cuff syndrome, $0.6 \%(\mathrm{n}=1)$ carpal tunnel syndrome and lateral epicondylitis, and $0.6 \%(\mathrm{n}=1)$ had three diagnostics: carpal tunnel syndrome, lateral epicondylitis, and rotator cuff syndrome.

In the institutional action protocol, physiotherapists noted evidence of cervical myofascial syndrome in $81.9 \%(\mathrm{n}=122)$ of the patients, rotator cuff syndrome in $73.8 \%(\mathrm{n}=110)$, lateral epicondylitis in $63.1 \%(n=94)$, and carpal tunnel syndrome in $51.1 \%(n=76)$ of users. The semiological trials also allowed to show that $92.6 \%(n=138)$ of all patients presented two or more pathologies (Figure 1).

Figure 2. Coexistence of musculoskeletal disorders in the upper body, according to physiotherapeutic evaluation.

\section{Coexistence of upper body musculoskeletal disorders}

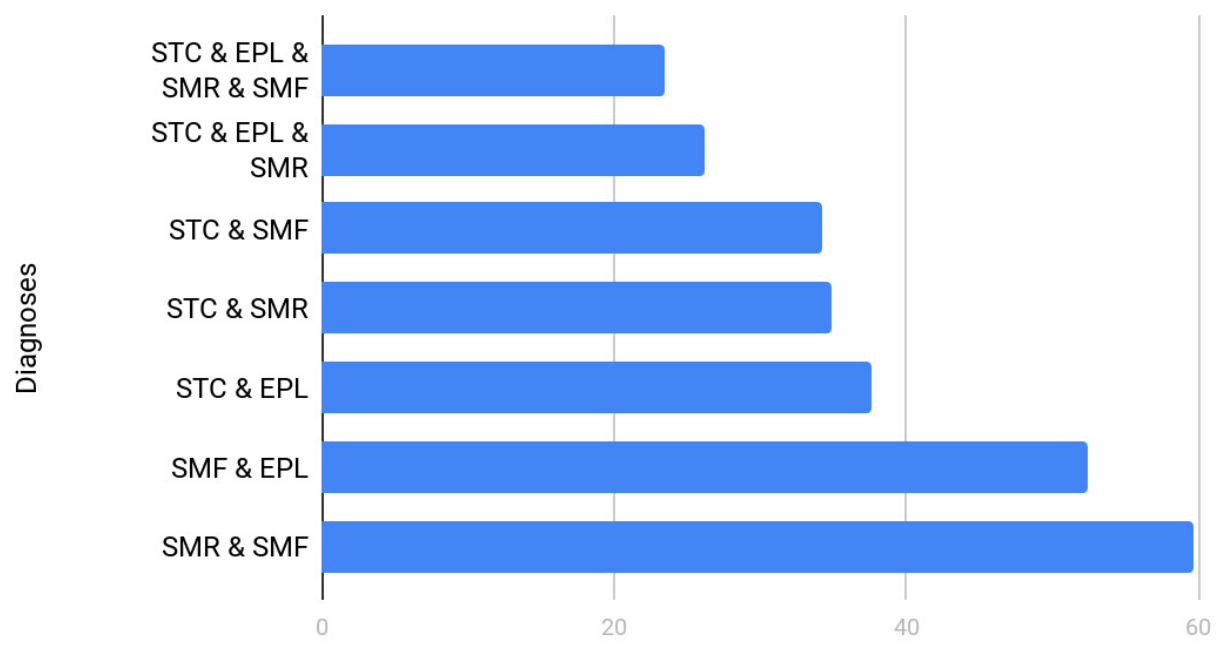

Percentage 
According to gender, the most commonly occurring osteomuscular injury in men was rotator cuff syndrome with a figure of $95.45 \%(n=42)$, followed by lateral epicondylitis with $61.3 \%(n=27)$. In women, the most commonly found disorder was cervical myofascial syndrome with a figure of $96.19 \%$ $(n=101)$, followed by rotator cuff syndrome with $90.48 \%(n=95)$. On the other hand, the most frequent coexistence of MSD in both men and women was cervical myofascial syndrome (Figure 2).

Figure 3. Coexistence of musculoskeletal disorders in the upper body according to gender. SMR (rotator cuff syndrome); SMF (myofascial syndrome); EPL (lateral epicondylitis); STC (carpal tunnel syndrome).

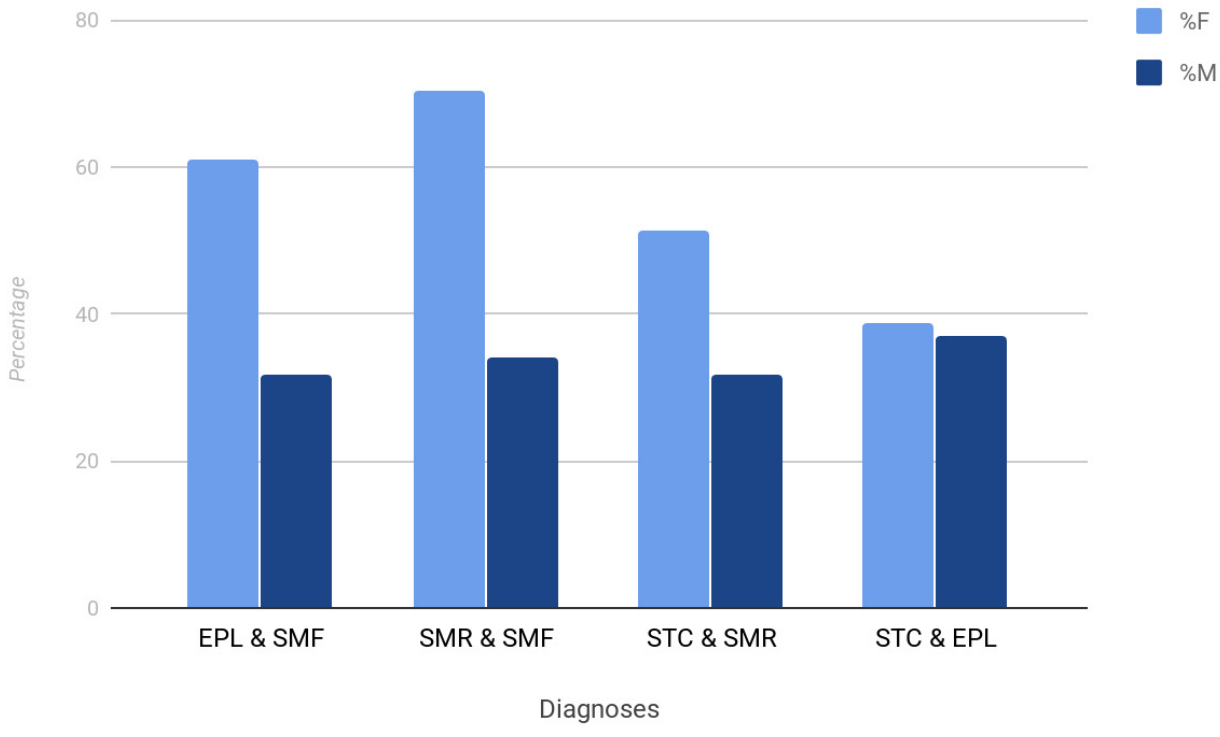

A statistically significant relationship was found between gender and rotator cuff syndrome with myofascial syndrome $(\mathrm{p}=0.00)$, epicondylitis with myofascial syndrome $(\mathrm{p}=0.00)$, and carpal tunnel syndrome with myofascial syndrome $(\mathrm{p}=0.02)$.

\section{DISCUSSION}

The hypothesis was that patients with musculoskeletal disorders with an origin in labour presented more than one osteomuscular alteration in one single extremity, of which were not completely diagnosed by the occupational or general physician and led the patient to an unfocused rehabilitation treatment obligating physiotherapeutic or health professionals to perform an exhaustive evaluation to identify the slow progress of the patient, and the deterioration in the patient's quality of life. This hypothesis was confirmed through the comparison between the coexistence of MSD in adults over the age of 50 and the doubled presence of women employed in paid work as well as being responsible for family and domestic chores as a risk factor ${ }^{15}$.

As to age, the results indicate a relationship directly proportional between age and total work experience, revealing a long time of exposure to occupational risk factors and therefore to suffer osteomuscular hurts. In one study completed in Lithuania by Kaliniene et $a^{16}$, it was found that the frequency of MSD is greater in adults older than 50 years old, which is concu- 
rred with the age of participants in this present investigation. Additionally, Kaliniene et $a l^{16}$ determined that these adults have between two to three times more of a chance of showing MSD in the shoulder, elbow, and wrist. Petreanu's ${ }^{17}$ opinion explains this by prolonged exposure to occupational demands that employees have throughout their professional lives, a situation which is reflected this this current study where patients have an average age of 50 years, exposure to occupational risk factors throughout at least 18 years (average) and coexistence of MSD in $92.6 \%$ of patients. However, it must be warned that recent changes in the organization of work have led to atypical trajectories, precarious work conditions, and unstable employment that make it difficult to relate age, work, and $\mathrm{MSD}^{17}$.

On the other hand, it was found that the gender that went most to rehabilitation due to MSD in the upper body was the feminine gender, coinciding with another investigation conducted in a call center in Bogota ${ }^{18}$ and a study from Central America about workers in all sectors ${ }^{19}$. In a similar fashion to this investigation, the highest percentage of the population that consulted IPS were women. To this it should be added that $100 \%$ of the participants had to meet the demands of their home and family, implying a greater workload and double the exposure to occupational risk factors. In the words of Ruiz et $a l^{15}$, this phenomenon has been called double presence and deepens osteomuscular lesions.

For its part, the European Agency for Safety and Health at Work ${ }^{20}$ highlights some occupational risk factors for women such as work in specific sectors, the physical differences when compared to men, the fact of having to balance double the responsibility in the workplace and at home, the execution of jobs that are erroneously cataloged as safe and easy but expose them to risks that increase their vulnerability to occupational ill- nesses. In this study, the most prevalent diagnosis in the female gender was myofascial syndrome. According to Nae J Dun J ${ }^{21}$, the ratio of women to men with this syndrome is approximately 9:1. Additional to this Muños $\mathrm{J}^{22}$ demonstrates that among its multiple causes one finds abnormal postures that are assumed during these work activities and points to absenteeism and inability to work as some of its main consequences.

The men, for their part, presented rotator cuff syndrome most often. However, in an epidemiological study conducted in the United Kingdom by White $\mathrm{J}$ et $a l^{23}$ it was found that this pathology was more common in women than in men (90 against 83 cases per 100,000 people). Razmjou et $a l^{24}$ explains that this situation is due not only to a woman's biological differences, but to the differences in gender from a social perspective in terms of access to resources or the inequalities that exist in order to be referred to a specialized evaluation.

As to the most common occupational diseases, the Second National Survey on Occupational Safety and Health Conditions of $2013^{25}$ reported carpal tunnel syndrome as the pathology best known by Occupational Risk Insurers with an average of $42.5 \%$, and rotator cuff syndrome and injuries or illnesses to the invertebrate disks as the fastest growing pathologies in 2012. Contrasting this, this investigation found that the most prevalent medical referral was rotator cuff syndrome, followed by carpal tunnel syndrome. Likewise, the semiological trials found rotator cuff syndrome as the second most frequent pathology.

In a similar manner, a systematic revision made by Costa $e t \mathrm{al}^{26}$ found that the incidence of rotator cuff syndrome shifted between 0.08 and 8 new cases per 100 workers, according to various activities and work conditions. In the same way, 
lateral epicondylitis varied from 0.45 to 7 new cases per 100 workers.

In terms of coexistence, in a study conducted in China by Feng et $a l^{27}$ it was found that $75 \%$ of dentists showed at least two MSDs in the upper body, of which $40 \%$ were bilateral disorders in the shoulder and $18 \%$ in the wrist. However, it must be emphasized the existing epidemiological data on these maladies is restricted to a specific structure and no record of these osteomuscular disorder is found, as well as records of physiotherapeutic diagnosis.

This investigation puts in evidence the coexistence of MSD through physiotherapeutic evaluation. It is a criteria of vital importance if one considers that this diagnostic is an opinion grounded on a rational critical analysis of all available information, as well as playing an important role in the security and safety at work as it can reduce the need for costly procedures, identify and prevent ailments, and promote wellness at work ${ }^{28}$.

Gallego $^{29}$ assures that medical diagnostics are an important element, but does not comprise sufficient information to direct the rehabilitation process. This research seeks to reevaluate therapeutic intervention from a concept of an anatomical "one structure" in an isolated manner and to incorporate the evaluation and treatment in a holistic way taking into account the likely presence of coexistence of MSD in each patient.

\section{LIMITATIONS AND RECOMMENDATIONS}

As limitations of this study it should be mentioned that the final diagnoses of doctors and physiotherapists were assumed to be correct without additional objective tests such as electromyography (EMG), nuclear magnetic resonances (NMR), or ultrasounds. It should also be noted that the diagnoses were assumed to be correct without establishing a causal relationship with the work activity performed, the analysis of workstation, ergonomic studies, and other analyzes of non-work factors.

Considering that the analysis was based on a relatively small population, it is recommended to expand upon the research of the coexistence of MSDs of work origin searching for an existing relationship between degree of occupation, work conditions, socioeconomic status, lifestyle, job analysis, non-work factors, and the agreement between medical and physiotherapeutic diagnoses, as well as developing performance protocols for health teams dealing with physical rehabilitation.

\section{CONCLUSION}

The coexistence of musculoskeletal ailments of work origin was present in a high percentage in the population of this study, with the most frequent appearances being rotator cuff syndrome and carpal tunnel syndrome, especially in the female gender. However, in the absence of objective confirmatory tests of the ailment as well as its relationship of causation as an ailment related to work, emerges the necessity to conduct investigations that show if there is an underdiagnosis on the part of the medical professionals or if on the contrary there is an overdiagnosis of work related ailments on the part of the physiotherapists.

\section{DECLARATION ABOUT CONFLICTS OF INTEREST}

The authors declare they have no conflict of interest in the execution of the work or the drafting of the manuscript. 


\section{BIBLIOGRAPHIC REFERENCES}

1. Organización Mundial de la Salud. Prevención de trastornos músculo-esqueléticos en el lugar de trabajo. France: OMS; 2004.

2. Ordoñez C, Gómez E, Calvo A. Desórdenes músculo esqueléticos relacionados con el trabajo. Revista Colombiana de Salud Ocupacional [Internet]. 2016 [cited 2017, March 11]; 6(1):2430. Retrieved from: http://revistasojs.unilibrecali. edu.co/index.php/rcso/article/view/307/534

3. Montano D. Upper body and lower limbs musculoskeletal symptoms and health inequalities in Europe: an analysis of crosssectional data. BMC Musculoskeletal Disorders [Internet]. 2014 [cited 2017, March 11];15(1). Doi: https://doi.org/10.1186/1471-2474-15-285

4. Chagas D. Prevalence and symptomatology of musculoskeletal problems reported by home care service workers caring for the elderly1. DYNA [Internet]. 2016 [cited 2017, March 11]; 83(197):17. Doi: http://dx.doi.org/10.15446/ dyna.v83n197.57585

5. Fasecolda :: Accion julio 292014 [Internet]. Fasecolda.com. 2014 [cited 2017, March 11]. Retrieved from: http://www.fasecolda.com/ index.php/sala-de-prensa/noticias/2014/ accion-julio-29-2014

6. Ministerio de la Protección Social. Guía de Atención Integral Basada en la Evidencia para Desórdenes Musculoesqueléticos (DME) relacionados con Movimientos Repetitivos de Miembros Superiores (Síndrome de Túnel Carpiano, Epicondilitis y Enfermedad de De Quervain (GATI- DME). Bogota: Javeriana University; 2006 p. 1-136.

7. Campos A, Delclos G, Douphrate D, Felknor S, Vargas-Prada S, Serra C et al. Upper extremity musculoskeletal pain among office workers in three Spanish-speaking countries: findings from the CUPID study. Occupational and Environmental Medicine [Internet]. 2016 [cited 2017, March 11];73(6):394-400. Doi: http:// dx.doi.org/10.1136/oemed-2015-103327.

8. Mohammadpour, H., Jalali, M., MoussaviNajarkola, S., Farhadi, S., Kangavari, M. and Ghanbari Sartang, A. (2018). Ergonomic Risk Assessment of Distal Upper Extremities by Job Strain Index in Carpet Weavers. Health Scope, 7(1)

9. Pilat A. Terapias miofasciales. Madrid: McGrawHill Interamericana; 2011.

10. Organización Internacional del Trabajo. ILO calls for urgent global action to fight occupational diseases [Internet]. 2013. Retrieved from: http:// www.ilo.org/global/about-the-ilo/newsroom/ news/WCMS_211627/lang--es/index.htm.

11. Gerstner Bruns, J. and Gerstner G, J. (n.d.). Semiología del aparato locomotor. 13th ed. Celsus, p.463.

12. Declaración de Helsinki de la Asociación Médica Mundial. Principios éticos para las investigaciones médicas en seres humanos Adoptada por la $18^{\text {a }}$ Asamblea Médica Mundial, Helsinki, Finland, June 1964.

13. Ministerio De Salud. Resolucion Numero 8430 De 1993 [Internet]. Invima.gov.co. 2017 [cited 2017, November 26]. Retrieved from: https:// www.invima.gov.co/images/pdf/tecnovigilancia/ buenas_practicas/normatividad/Resolucion_8430_ de_1993.pdf.

14. Ley Estatutaria 1581 De 2012 [Internet]. Alcaldiabogota.gov.co. 2017 [cited 2017, November 26]. Retrieved from: http://www.alcaldiabogota.gov. co/sisjur/normas/Normal.jsp?i=49981

15. López PR, Tapia PP, Parra CAP, Zamora-Sánchez R. La doble presencia en las trabajadoras femeninas: equilibrio entre el trabajo y la vida familiar. Revista de Comunicación de la SEECI. 2018(44):33-51. 
16. Kaliniene G, Ustinaviciene R, Skemiene L, Vaiciulis V, Vasilavicius P. Associations between musculoskeletal pain and work-related factors among public service sector computer workers in Kaunas County, Lithuania. BMC Musculoskeletal Disorders [Internet]. 2016 [cited 2017, March 11];17(1). Doi: https://doi. org/10.1186/s12891-016-1281-7.

17. Petreanu V, Seracin A. Risk factors for musculoskeletal disorders development: hand-arm tasks, repetitive work - OSHWiki [Internet]. Oshwiki.eu. 2016 [cited 2017, August 11]. Retrieved from: https://oshwiki.eu/wiki/ Risk_factors_for_musculoskeletal_disorders_ development:_hand-arm_tasks,_repetitive_work

18. Orjuela A. Prevalencia de síntomas osteomusculares en miembros superiores en trabajadores de un call center de Bogotá Colombia durante el año 2015. Bogota; 2015.

19. Rojas M, Gimeno D, Vargas S, Benavides F. Dolor musculoesquelético en trabajadores de América Central: resultados de la I Encuesta Centroamericana de Condiciones de Trabajo y Salud. Rev Panam Salud Publica [Internet]. 2015;38(2):120-8. Retrieved from: https:// scielosp.org/pdf/rpsp/2015.v38n2/120-128

20. Las mujeres y la seguridad y salud en el trabajo - Salud y seguridad en el trabajo - EU-OSHA [Internet]. Osha.europa.eu. 2018 [cited 2017, March 11]. Retrieved from: https://osha.europa. eu/es/themes/women-and-health-work

21. Nae J Dun J. Chronic Pain: Myofascial Pain and Fibromyalgia. International Journal of Physical Medicine \& Rehabilitation [Internet]. 2013 [cited 2017, March 11];01(06). Doi: http://doi: 10.4172/2329-9096.1000e102

22. Muñoz J, Alpizar D. Síndrome Miofascial. Medicina Legal de Costa Rica - Edición Virtual [Internet]. 2016 [cited 2017, January 11];33(1):19. Retrieved from: http://www.scielo.sa.cr/pdf/ $\mathrm{mlcr} / \mathrm{v} 33 \mathrm{n} 1 / 1409-0015-\mathrm{mlcr}-33-01-00219 . \mathrm{pdf}$
23. White J, Titchener A, Fakis A, Tambe A, Hubbard R, Clark D. An epidemiological study of rotator cuff pathology using The Health Improvement Network database. The Bone \& Joint Journal [Internet]. 2014 [cited 2017, September 11];96-B(3):350-353. Doi: https://doi. org/10.1302/0301-620X.96B3.32336

24. Razmjou H, Lincoln S, Macritchie I, Richards R, Medeiros D, Elmaraghy A. Sex and gender disparity in pathology, disability, referral pattern, and wait time for surgery in workers with shoulder injury. BMC Musculoskeletal Disorders [Internet]. 2016 [cited 2017, November 11];17(1). Doi: https://doi.org/10.1186/s12891-016-1257-7

25. Ministerio de Trabajo, República de Colombia. Informe Ejecutivo Ii Encuesta Nacional De Condiciones De Seguridad Y Salud En El Trabajo En El Sistema General De Riesgos. Bogota: GRAFIQ EDITORES S.A.S; 2013 p. 1-56.

26. daCostaJ,BaptistaJ,VazM.Incidence and prevalence of upper-limb work related musculoskeletal disorders: A systematic review. Work [Internet]. 2015 [cited 2017, April 11];51(4):635-644. Doi: http://dx.doi.org/10.3233/WOR-152032

27. Feng B, Liang Q, Wang Y, Andersen L, Szeto G. Prevalence of work-related musculoskeletal symptoms of the neck and upper extremity among dentists in China. BMJ Open [Internet]. 2014 [cited 2017, September 11];4(12):e006451. Doi: http:// dx.doi.org/10.1136/bmjopen-2014-006451

28. Moreira R, Sato T, Foltran F, Silva L, Coury H. Prevalence of musculoskeletal symptoms in hospital nurse technicians and licensed practical nurses: associations with demographic factors. Brazilian Journal of Physical Therapy [Internet]. 2014 [cited 2017, April 11];18(4):323-333. Doi: http://dx.doi.org/10.1590/bjpt-rbf.2014.0026

29. Gallego T. Bases Teóricas y Fundamentos de la Fisioterapia. 1st ed. Bogotá: Panamericana; 2018.

30. Hormiga M. Manual deSemiología Osteomuscular para Fisioterapeutas. 1st ed. Popayán: Editorial Universidad Del Cauca; 2019. 